Article

\title{
Mineralogical Study of a Biologically-Based Treatment System That Removes Arsenic, Zinc and Copper from Landfill Leachate
}

\author{
Maryam Khoshnoodi ${ }^{1}$, Gregory Dipple ${ }^{2}$ and Susan A. Baldwin ${ }^{1, *}$ \\ ${ }^{1}$ Department of Chemical and Biological Engineering, University of British Columbia, 2360 East Mall, \\ Vancouver, BC V6T 1Z4, Canada; E-Mail: mkhoshnoodi@chbe.ubc.ca \\ ${ }^{2}$ Department of Earth, Ocean and Atmospheric Sciences, University of British Columbia, 2207 Main \\ Mall, Vancouver, BC V6T 1Z4, Canada; E-Mail: gdipple@eos.ubc.ca \\ * Author to whom correspondence should be addressed; E-Mail: sbaldwin@ mail.ubc.ca; \\ Tel.: +1-604-822-1973; Fax: +1-604-822-6003.
}

Received: 20 October 2013; in revised form: 27 November 2013 / Accepted: 5 December 2013 / Published: 16 December 2013

\begin{abstract}
Mineralogical characterization by X-ray diffraction (XRD) and a high throughput automated quantitative evaluation of minerals by scanning electron microscopy (QEMSCAN) was conducted on samples from a sulphate-reducing biochemical reactor (BCR) treating high concentrations of metals ( $\mathrm{As}, \mathrm{Zn}, \mathrm{Cu}$ ) in smelter waste landfill seepage. The samples were also subjected to energy dispersive X-ray (EDX) analysis of specific particles. The bulk analysis results revealed that the samples consisted mainly of silicate and carbonate minerals. More detailed phase analysis indicated four different classes: zinc-arsenic sulphosalts/sulphates, zinc-arsenic oxides, zinc phosphates and zinc-lead sulphosalts/sulphates. This suggests that sulphates and sulphides are the predominant types of $\mathrm{Zn}$ and As minerals formed in the BCR. Sphalerite $(\mathrm{ZnS})$ was a common mineral observed in many of the samples. In addition, X-ray point analysis showed evidence of As and $\mathrm{Zn}$ coating around feldspar and amphibole particles. The presence of arsenic-zinc-iron, with or without cadmium particles, indicated arsenopyrite minerals. Copper-iron-sulphide particles suggested chalcopyrite $\left(\mathrm{CuFeS}_{2}\right)$ and tennantite $(\mathrm{Cu}, \mathrm{Fe})_{12} \mathrm{As}_{4} \mathrm{~S}_{13}$. Microbial communities found in each sample were correlated with metal content to describe taxonomic groups associated with high-metal samples. The research results highlight mineral grains that were present or formed at the site that might be the predominant forms of immobilized arsenic, zinc and copper.
\end{abstract}


Keywords: arsenic; zinc; copper; biochemical reactor; geomicrobiology; biomineralization; QEMSCAN; mining

\section{Introduction}

Constructed wetland systems using organic waste substrates and limestone or lime were first used to treat acid rock drainage at coal mines [1] and, since then, have been adopted for the treatment of many other mine-influenced waters [2-5]. Most effective for removal of metals, such as arsenic and zinc, are subsurface flow anaerobic systems, currently referred to as biochemical reactors (BCRs) [6,7]. Microbial activity within the organic-rich matrix creates alkalinity and reducing conditions that are conducive for metal precipitation at circumneutral $\mathrm{pH}$ values. Furthermore, when sulphate is present in the influent, sulphate-reducing bacteria produce sulphide, which combines with metal cations to form sparingly soluble metal sulphides [8-10].

Other metal removal mechanisms are possible within BCRs, such as the filtration of suspended solids and the adsorption to the organic material [11] or the limestone, sands and clays [12] that may be part of the reactor matrix. Microbes themselves and their extra-polymeric substances possess metal ion binding moieties that can provide nucleation sites that facilitate mineral formation [13-16]. Even intracellular accumulation of metals can occur [17]. In addition, there is evidence that microbial iron reduction also controls the formation of metal precipitates [18]. In some cases, iron reduction and/or arsenate reduction by bacteria, such as Shewanella sp., leads to the release of As(III) [19,20], but in other instances, the inoculation of arsenic- and iron-reducing bacteria into ferrihydrite coated sand columns resulted in greater sequestration of As compared with the abiotic columns [21].

Despite the potential for effective metal removal using microbially-based treatment, reliance on these BCRs to meet regulatory requirements at mine sites has been hampered by their unreliability, unknown longevity and insufficient information on the state and long-term fate of the metals contained in them. Very few studies have been done to determine the actual mineralogical forms of metals in these complex bioreactors, due to the difficulty of obtaining representative samples, the rarity of these minerals within the largely organic-rich matrix and the interference of the organic compounds present in mineralogical analytical procedures. To make up for this dearth of information on mineral formation in BCRs and to postulate on the relative importance of the various mechanisms, mineralogical data were collected from a bioreactor that had been removing arsenic and zinc successfully for ten years.

The zinc-arsenic mineral, köttigite $\left(\mathrm{Zn}_{3}\left(\mathrm{AsO}_{4}\right)_{2} \cdot 8 \mathrm{H}_{2} \mathrm{O}\right)$, was identified, using X-ray diffraction (XRD), in the smelter landfill seepage flowing into the BCR [5]. This mineral is stable under aerobic conditions and was speculated to dissolve once inside the anaerobic bioreactor. Preliminary studies on minerals present in the bioreactor solids, done during a 2002 reconstruction, suggested the formation of zinc sulphides based on scanning electron microscope (SEM) images and energy-dispersive X-ray spectroscopy (EDX) [5]. Similarly, small spheroidal aggregates of zinc sulphide minerals, such as sphalerite and wurtzite, were identified using SEM-EDX and synchrotron-X-ray diffraction in mining-affected environments, where sulphate-reducing bacteria were active [22-24], supporting that 
these minerals are very likely to form in BCRs treating $\mathrm{Zn}$ contaminated waters. A comprehensive survey of all types of zinc minerals formed in the BCR had not been done prior to the current study.

Arsenic is a toxic by-product of mining that poses specific challenges for treatment, since it exists in solution as metalloids, arsenate $\left(\mathrm{As}(\mathrm{V}) \mathrm{O}_{4}^{3-}\right)$ and arsenite $\left(\mathrm{As}(\mathrm{III}) \mathrm{O}_{3}^{2-}\right)$. These forms of arsenic can be transformed directly by microbes with arsenate acting as an electron acceptor for dissimilatory arsenic respiring prokaryotes (DARPs) [25] and arsenite serving as an electron donor for arsenic oxidizing bacteria (AOBs) [26]. Bacterial detoxification mechanisms involve the reduction of arsenate to arsenite. Indeed, a laboratory study using pulp mill biosolids from the BCR identified, using XANES, a mixture of $\mathrm{As}(\mathrm{III})-\mathrm{O}$ and disordered $\mathrm{As}_{2} \mathrm{~S}_{3}$ in the final solids from reactors treating $\mathrm{As}(\mathrm{V})$ and $\mathrm{SO}_{4}^{2-}$ containing influent [27]. Interestingly, the addition of zinc to the influent increased the amount of arsenic removed through an unknown mechanism. These observations were based on laboratory experiments and may not reflect the actual conditions and mineralogical forms of arsenic present in the field bioreactor.

The availability of new methods for mineralogical analysis has allowed us to make new observations and gain new insights into the mechanisms at play in BCRs. In this study, using samples from the BCR that had been removing $\mathrm{Zn}$ and As successfully for over ten years, an automated mineralogical method, QEMSCAN (quantitative evaluation of minerals by scanning electron microscopy) [28], was applied for a comprehensive survey of the mineralogical forms present. The results were compared with other, more conventional methods, such as X-ray diffraction. To overcome the interference of organic material, a low temperature ashing procedure was developed to remove the organics prior to analysis. Metal and mineralogical composition of the samples were correlated with their microbial community structure, which was determined using next generation DNA sequencing, as described elsewhere [29]. Putative sulphate- and iron-reducing bacteria and other microbial groups that correlated with the high metal content of the samples were identified.

\section{Experimental Section}

\subsection{Sampling Site Characterization}

The biochemical reactor (BCR) selected for this study received metal and sulphate-rich seepage from a smelter-waste landfill [5]. A schematic of the BCR is included in the Supplemental Information, Figure S1. The BCR was reconstructed in 2002 with a mixture of pulp mill biosolids, iron-coated sand and limestone. Samples were collected from cores removed by drilling into the reactor matrix at three different locations and on three different days: 22 July 2008 (samples TS1, TS2 and TS3), 19 April 2009 (samples TS4, TS5 and TS6) and 20 October 2009 (samples TS7, TS8 and TS9). Considerable effort was needed to access the BCR biosolids, which were below more than $1 \mathrm{~m}$ of soil and sand. A portable diamond drilling rig was used to allow the withdrawal of the cores inside $2.0 \mathrm{~cm}$ internal diameter poly vinyl chloride (PVC) pipe that was then sectioned into approximately $30-40 \mathrm{~cm}$ lengths. The core samples were frozen using liquid $\mathrm{N}_{2}$ immediately after removal. In the laboratory, each core was sectioned into $5 \mathrm{~cm}$ intervals, each of which was homogenized by grinding under liquid $\mathrm{N}_{2}$ and used for chemistry, phylogenetic and mineralogical analyses. In the field, pore water environmental variables, such as $\mathrm{pH}$, dissolved oxygen (DO), oxidation/reduction potential (ORP) and temperature, were measured with a YSI 6920 multi-probe sonde (YSI Inc., Yellow Springs, OH, USA). The average 
total concentrations of arsenic (T/As), zinc (T/Zn) and sulphate in the BCR influent during the sampling period of 25 June 2008 to 2 October 2009 were 33.2, 71.1 and $654.1 \mathrm{mg} / \mathrm{L}$, respectively. The average total concentrations of arsenic (T/As) and zinc (T/Zn) decreased to 8.8 and $34.3 \mathrm{mg} / \mathrm{L}$, respectively, which demonstrated a high metal removal efficiency within the BCR. The overall treatment system of two anaerobic BCRs, three plant cells and a settling pond achieved 99.97\% total As removal [5]. The sulphate concentrations were highly variable during this period. The average total suspended solids entering the BCR between July 2008 and October 2009, was $168.5 \mathrm{mg} / \mathrm{L}$, which decreased to $82.7 \mathrm{mg} / \mathrm{L}$ in the effluent.

\subsection{Core Solids Chemistry}

Characterization of major elements, base metals, trace elements, volatiles, as well as total nitrogen, carbon and sulphur were determined at the ALS Minerals Division analytical laboratory, Geochemistry Group (2103 Dollarton Highway, North Vancouver, BC, Canada). Base metals, such as $\mathrm{Cu}$ and Zn, were decomposed using a four acid digestion $\left(\mathrm{HNO}_{3}-\mathrm{HClO}_{4}-\mathrm{HF}-\mathrm{HCl}\right)$ followed by inductively coupled plasma-atomic emission spectroscopy (ICP-AES). For major mineral (such as $\mathrm{Fe}_{2} \mathrm{O}_{3}$ ) analysis, the samples were decomposed by lithium metaborate/lithium tetraborate $\left(\mathrm{LiBO}_{2} / \mathrm{Li}_{2} \mathrm{~B}_{4} \mathrm{O}_{7}\right)$ fusion and then analyzed using ICP-AES. Aqua regia digestion was used for arsenic detection with inductively-coupled plasma-mass spectroscopy (ICP-MS). For total sulphur analysis, the sample was decomposed in a Leco Furnace (Leco Corp., St Joseph, MI, USA) and measured with infrared spectroscopy.

\subsection{Pretreatment of Core Samples: Organic Matter (OM) Removal}

The presence of significant amounts of organic matter (OM) in samples for mineralogical analysis can interfere with X-ray diffraction and scanning electron (SEM) microscopy analysis; therefore, an effective method for the removal of OM from the solid samples without changing their inorganic phases was required before mineralogical assessment. Core samples obtained from the biochemical reactor contain high amounts of organic matter (from $1.7 \mathrm{wt} \%$ to $13.2 \mathrm{wt} \%$ total organic carbon (TOC)). For this purpose, low temperature ashing (LTA) was applied, which uses radio frequency radiation to excite oxygen to remove $\mathrm{OM}$ from the samples at temperatures below $100{ }^{\circ} \mathrm{C}$ [30]. A plasma asher (Planer EtchII, Technics West Inc., Cranston, RI, USA) was used, and the LTA reaction was carried out at 0.550 torr $(0.73 \mathrm{mbar}), 25{ }^{\circ} \mathrm{C}$ and at a radio frequency $(\mathrm{RF})$ power of $70 \mathrm{~W}$ for $1 \mathrm{~h}$. Radio frequency radiation dissociates, ionizes and excites oxygen molecules into chemically excited atoms, which removes OM from the samples. For optimum results, the reaction was stopped after $30 \mathrm{~min}$, and samples were stirred and reloaded for an additional $30 \mathrm{~min}$.

\subsection{Mineralogical Analysis}

\subsubsection{XRD (X-Ray Diffraction)}

Mineralogical analysis was used to identify the chemical forms of the metals in the solid phase. For these types of samples, the collection of accurate mineralogical data is limited by the poor 
crystallinity of the precipitates and their rarity, particularly for arsenic minerals, in the sample. A D8 Focus Bragg-Brentano diffractometer (Bruker, Karlsruhe, Germany) and a D5000 Bragg-Brentano diffractometer (Siemens (Bruker), Karlsruhe, Germany) at the Electron Microbeam/X-Ray Diffraction Facility, University of British Columbia, were used for collecting diffraction data for qualitative analysis of the treated samples and preliminary mineral characterization. Diffraction data were processed by automated "search-match" software, which makes use of the International Centre for Diffraction Data PDF-4+ database (International Centre for Diffraction Data (ICDD), Newtown Square, PA, USA). The minerals identified by these methods were compared with the quantitative evaluation of minerals by scanning electron microscopy (QEMSCAN) bulk mineral analysis results (method described below).

\subsubsection{QEMSCAN (Quantitative Evaluation of Minerals by Scanning Electron Microscopy)}

QEMSCAN is a scanning electron microscope (SEM) that provides rapid automated quantitative mineral analysis using Backscattered Electrons (BSE) (Bruker) and up to four energy dispersive X-ray (EDX) spectrometers. Nine representative subsamples taken from the BCR core samples were mounted into epoxy resin blocks. Standard sized, polished, thin sections were carbon coated and analyzed at the ALS Metallurgy Laboratory (2957 Bowers Place, Kamloops, BC V1S 1W5, Canada) using a QEMSCAN Quanta 650W (FEI Academy, Brisbane, Australia). Two modes of QEMSCAN analysis were used: bulk mineral analysis (BMA) and particle mineral analysis (PMA). BMA provides information on mineral composition, and PMA identifies the details of the mineral fragmentation characteristics (liberation and association) of minerals. In fact, the PMA mode creates digital images by using BSE and EDX signals from SEM, and each pixel in the image corresponds to mineral species in a small region under the electron beam. The individual particles section was scanned by this method, and BSE and EDX photons emanating from a given point were used to identify the elements present. The measured spectra were compared against a database of known spectra, and a mineral or phase name was assigned to each measurement by the QEMSCAN computer software. X-ray spot analysis was applied to specific mineral forms for further identification and verification of mineral phases present. More details on the operation of the system is given in [28,31]. In keeping with the goal of the BCR, the focus was on arsenic- and zinc-bearing minerals.

\subsection{Geochemical Modeling}

In order to predict the formation of arsenic-bearing minerals under the physico-chemical conditions present at the site, Eh-pH diagrams for the system of As-Fe-S-O-H were constructed using the Spana (was Hydra and Medusa) chemical equilibria computing software package and database, version 2.0, 10 April 2013 [32-34]. Arsenic species equilibria constants were updated based on the most recent literature, as reported in Tables 1 and 2 of Lu and Zhu [35]. Predominant As species in the As-Fe-S-O-H system were predicted over the range of total As, Fe and S concentrations measured in the BCR influent, effluent, lysimeter and borehole pore water (Tables S1-S3 in the Supplemental Information). The input file containing all the species, their $\log (\mathrm{K})$ values and stoichiometric coefficients in terms of $\mathrm{H}^{+}, \mathrm{e}^{-}$, $\mathrm{HS}^{-}, \mathrm{As}(\mathrm{OH})_{3}$ and $\mathrm{Fe}^{2+}$ are shown in Table S4 of the Supplemental Information. 


\subsection{Correlation with Microbial Communities}

The microbial community composition in each of the BCR samples was determined by extracting DNA and using Roche454 titanium sequencing of the amplified V6 to V8 region of the small subunit ribosomal ribonucleic acids (SSU rRNA), as described previously [29,36]. The sequences were binned into so-called operational taxonomic units (OTUs) based on 97\% similarity, which represent putative microbial species. A representative sequence from each OTU was compared with a curated database (Silva111 [37]), so as to assign a taxonomic classification. The closest cultured relatives to the OTUs found in the BCR were found by using the program, Blastn, to search the National Center for Biotechnology Information (NCBI) 16S ribosomal RNA sequences (Bacteria and Archeae) database [38]. Phylogenetic compositions of the samples were compared using UNIFRAC [39] and visualized with principle component analysis implemented with the QIIME suite of Python scripts [40]. UNIFRAC evaluates the similarities between microbial communities from different samples or sites based on their phylogenetic relatedness. Particular microbial groups that were more prevalent in high metal content samples were identified. Furthermore, the types of putative sulphate-reducing bacteria and iron-reducing environment-related groups present in the BCR were determined based on taxonomic classification of the OTU representative sequences.

\section{Results}

The BCR under study had been operating successfully for ten years. During the five-year period from 2003 to $2007,2691 \mathrm{~kg}$ of arsenic, $6930 \mathrm{~kg}$ of zinc and $85 \mathrm{~kg}$ of cadmium were removed from approximately $25,550 \mathrm{~m}^{3}$ of treated water [5]. Biweekly sampling undertaken as part of the present study from June 2008 to June 2009, revealed average concentrations of dissolved arsenic and zinc entering the BCR of $2.3 \pm 1.0 \mathrm{mg} / \mathrm{L}$ and $39.5 \pm 7.5 \mathrm{mg} / \mathrm{L}$, respectively. These decreased to $1.2 \pm 1.1 \mathrm{mg} / \mathrm{L}$ and $27.3 \pm 7.4 \mathrm{mg} / \mathrm{L}$, respectively, in the BCR effluent. At the time of sampling, conditions in the BCR were reducing, and the $\mathrm{pH}$ was neutral to slightly basic (Table 1). The ORP was challenging to measure during the April sampling, and no stable values were obtained. During the spring and fall samplings, there was some oxygen measured in the pore water, whereas during the summer, no detectable oxygen was present. The temperatures varied from $19.4{ }^{\circ} \mathrm{C}$ in the summer to $6.5^{\circ} \mathrm{C}$ in the spring. Some of the samples contained significantly more metals (TS4 and TS7) than the others. The organic content of the BCR solids varied widely with $1.74 \%$ to $13.28 \%$ total organic carbon (TOC).

\subsection{Geochemical Predictions}

Geochemical modelling of the As-Fe-S-O-H system using total As, Fe and $\mathrm{S}$ values within the ranges measured at the site revealed that realgar (AsS), crystalline As and arsenopyrite (FeAsS) were all possible predominant forms of As under the $\mathrm{Eh}$ and $\mathrm{pH}$ conditions in the bioreactor (Table S5 and Figure S2, Supplemental Information) depending on the total As and Fe concentrations. The total S concentration was kept at $7 \mathrm{mM}$ for the geochemical modelling study. The effect of increasing Fe concentrations was to increase the stability range for arsenopyrite, such that, at the average BCR influent concentrations of total As, Fe and $\mathrm{S}(0.44,0.23$ and $7.00 \mathrm{mM}$, respectively), arsenopyrite was the only predicted predominant 
form (Figure 1). The formation of orpiment $\left(\mathrm{As}_{2} \mathrm{~S}_{3}\right)$ and realgar (AsS) could be possible under less reducing and more acidic conditions. At lower total Fe concentrations, modelling predicted that realgar and orpiment would be predominant over wider $\mathrm{pH}$ ranges, including the $\mathrm{pH}$ values measured in the BCR in the case of realgar (Figure S2, Supplemental Information).

Table 1. Pore water and bulk solids chemistry measured in the core sections collected from the BCR.

\begin{tabular}{|c|c|c|c|c|c|c|c|c|c|}
\hline SampleID & TS1 & TS2 & TS3 & TS4 & TS5 & TS6 & TS7 & TS8 & TS9 \\
\hline Date & \multicolumn{3}{|c|}{22 July 2008} & \multicolumn{3}{|c|}{21 April 2009} & \multicolumn{3}{|c|}{20 October 2009} \\
\hline $\begin{array}{l}\text { Pore water chemistry } \\
\text { pH } \\
\text { Eh }(\mathrm{mV}) \\
\mathrm{DO}(\mathrm{mg} / \mathrm{L}) \\
\mathrm{T}\left({ }^{\circ} \mathrm{C}\right)\end{array}$ & $\begin{array}{r}5.6 \\
-133 \\
0 \\
17.6\end{array}$ & $\begin{array}{r}5.6 \\
-112 \\
0 \\
15.9\end{array}$ & $\begin{array}{r}6.9 \\
-238 \\
0 \\
19.4\end{array}$ & $\begin{array}{c}6.9 \\
\text { NA }^{1} \\
1.5 \\
7.6\end{array}$ & $\begin{array}{c}6.9 \\
\text { NA } \\
1.1 \\
6.5\end{array}$ & $\begin{array}{c}7.0 \\
\text { NA } \\
0.7 \\
7.1\end{array}$ & $\begin{array}{r}6.7 \\
-118 \\
1.2 \\
11.2\end{array}$ & $\begin{array}{r}6.2 \\
-244 \\
1.3 \\
11.5\end{array}$ & $\begin{array}{r}7.5 \\
-130 \\
1.3 \\
11.2\end{array}$ \\
\hline $\begin{array}{l}\text { Solids analysis } \\
\mathrm{As}(\mathrm{ppm}) \\
\mathrm{Zn}(\mathrm{ppm}) \\
\mathrm{Cu}(\mathrm{ppm}) \\
\mathrm{Fe}_{2} \mathrm{O}_{3}(\%) \\
\mathrm{S}(\%) \\
\mathrm{TOC}(\mathrm{mg} / \mathrm{L})\end{array}$ & $\begin{array}{r}2.7 \\
108 \\
32 \\
1.58 \\
0.24 \\
4.46\end{array}$ & $\begin{array}{r}2.9 \\
122 \\
15 \\
1.36 \\
0.19 \\
4.29\end{array}$ & $\begin{array}{r}1.8 \\
118 \\
11 \\
1.86 \\
0.11 \\
3.17\end{array}$ & $\begin{array}{r}>250 \\
1735 \\
79 \\
\mathrm{NA} \\
\mathrm{NA} \\
5.20\end{array}$ & $\begin{array}{r}16.6 \\
180 \\
22 \\
2.12 \\
0.31 \\
8.70\end{array}$ & $\begin{array}{r}18.9 \\
177 \\
19 \\
2.24 \\
0.38 \\
8.00\end{array}$ & $\begin{array}{r}45.8 \\
705 \\
21 \\
1.29 \\
0.27 \\
13.28\end{array}$ & $\begin{array}{r}9.3 \\
127 \\
12 \\
2.35 \\
0.15 \\
2.69\end{array}$ & $\begin{array}{r}18.9 \\
380 \\
12 \\
1.88 \\
0.09 \\
1.74\end{array}$ \\
\hline
\end{tabular}

Note: ${ }^{1}$ not available; data were not measured.

Figure 1. Eh-pH diagram for As-Fe-S-O-H at $25{ }^{\circ} \mathrm{C}$ and 1 atm pressure. Predominant arsenic species predicted for the chemistry of the BCR pore water at: total arsenic, $0.44 \mathrm{mM}$; total sulphur, $7.00 \mathrm{mM}$; total iron, $0.23 \mathrm{mM}$. Solid species and stable (equilibrium) phases are indicated with the dark field. Diagram produced from Spana software $[33,34]$.

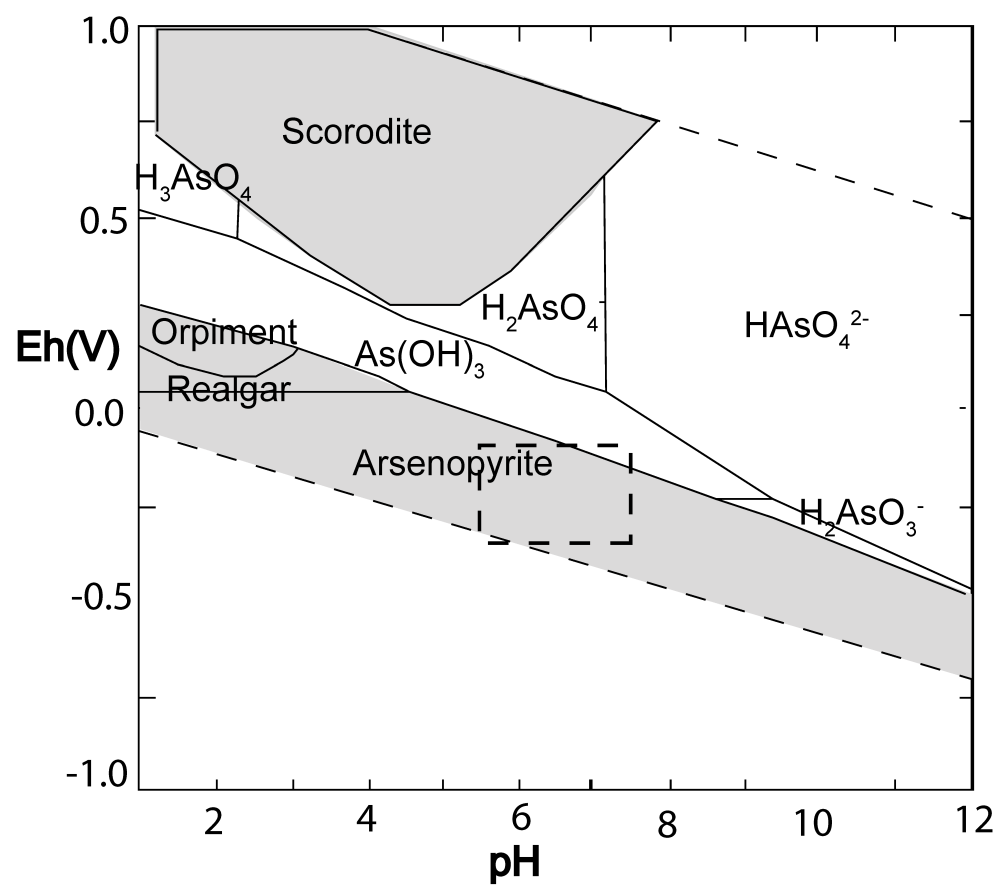




\subsection{Mineral Species Based on XRD Analysis}

XRD analysis revealed that the principal minerals were silicates and carbonates. Quartz, calcite, feldspar (albite, orthoclase), amphibole (actinolite, ferro-actinolite), chlorite (clinochlore), hauyne and muscovite were present in almost all samples. Small amounts of sulphides, sulphates and arsenates were also detected. Zinc sulphide (sphalerite) and iron sulphides (arsenopyrite, pyrite) were identified by XRD in some of the samples. Oxides and hydroxides were also identified, such as manganoan franklinite and magnetite (Table 2). This analysis is a qualitative approach, and detecting all diffraction spectra of the trace minerals depends on the detection limit of the XRD analyzer. Therefore, XRD cannot be used to definitively detect the formation of sphalerite or other sulphide and sulphate rare minerals, unless they are present in high enough amounts. To verify the formation of these minerals, further analysis was performed, as described next.

\subsection{QEMSCAN and X-Ray Analysis Observations}

By using QEMSCAN bulk mineral analysis (BMA), a more thorough mineralogical composition was obtained for some subsamples by quantifying all the mineral phases identified. Confirming the XRD analysis, samples consisted mainly of silicates (quartz, feldspars, chlorite, amphibole, epidote, muscovite, hauyne, biotite, clay, talc and sphene) and carbonates (calcite, dolomite). The main minerals, quartz, calcite and feldspar (plagioclase and alkali feldspar), represented between $9.2 \%$ and $29.9 \%$ of the subsamples. Phosphates (apatite) were also detected and represented around 0.3\%. The BMA analysis quantified the amounts of trace minerals, such as pyrite, arsenopyrite and iron oxides. Small amounts $(<0.1 \%)$ of zinc-, arsenic-, copper- and lead-bearing minerals were found in all samples. Possible forms of zinc minerals are as carbonates, arsenic oxides, sulphates, sulphides and phosphates. Arsenic was present as oxides and sulphides. Table 2 shows the abundance of these minerals. Sample TS2, in particular, contained significant amounts of $\mathrm{Zn}$ and As minerals (sphalerite, arsenopyrite, tennantite and zinc sulphate). Iron oxides were highest in sample TS5 and included limonite, goethite, magnetite and hematite. This sample also had a significant amount of arsenopyrite.

To further interrogate the forms of the arsenic- and zinc-bearing minerals, which were challenging to detect, due to their relatively low concentrations, a hybrid particle mineral analysis (PMA) was performed on each sample using QEMSCAN supported by EDX analysis. The PMA analysis revealed that some mineralogical forms were located in close proximity to each other or in association with each other. Figures 2 and 3 present selected particles that were analyzed by this method. In general, the trace minerals were grouped into four different classes: zinc-arsenic oxides; and zinc-lead sulphosalts/sulphates, zinc-arsenic sulphosalts/sulphates and zinc phosphates.

In one particle, zinc and arsenic were present as oxides. This particle contained up to $25.6 \%$ arsenic and $27.4 \%$ zinc and was associated with the bright phases of a multiplex grain. X-ray analysis suggested co-occurrence with feldspar (data not shown).

Zinc sulphate minerals were identified, such as zinc-aluminum sulphate, zinc-lead sulphates and zinc sulphates. Zinc-aluminum sulphates corresponded to the mineral, zinc woordite $\left.\left(\left(\mathrm{Zn}_{1-\mathrm{x}} \mathrm{Al} \mathrm{x}_{\mathrm{x}}\right)(\mathrm{OH})_{2}\right)\left(\mathrm{SO}_{4}\right)_{\mathrm{x} / 2}\right)$, according to the XRD spectra. 
Table 2. Mineralogical composition of the biochemical reactor (BCR) samples as determined by XRD, energy dispersive X-ray (EDX) and quantitative evaluation of minerals by scanning electron microscopy (QEMSCAN). BMA, bulk mineral analysis (percent weight of the total sample, unless otherwise specified).

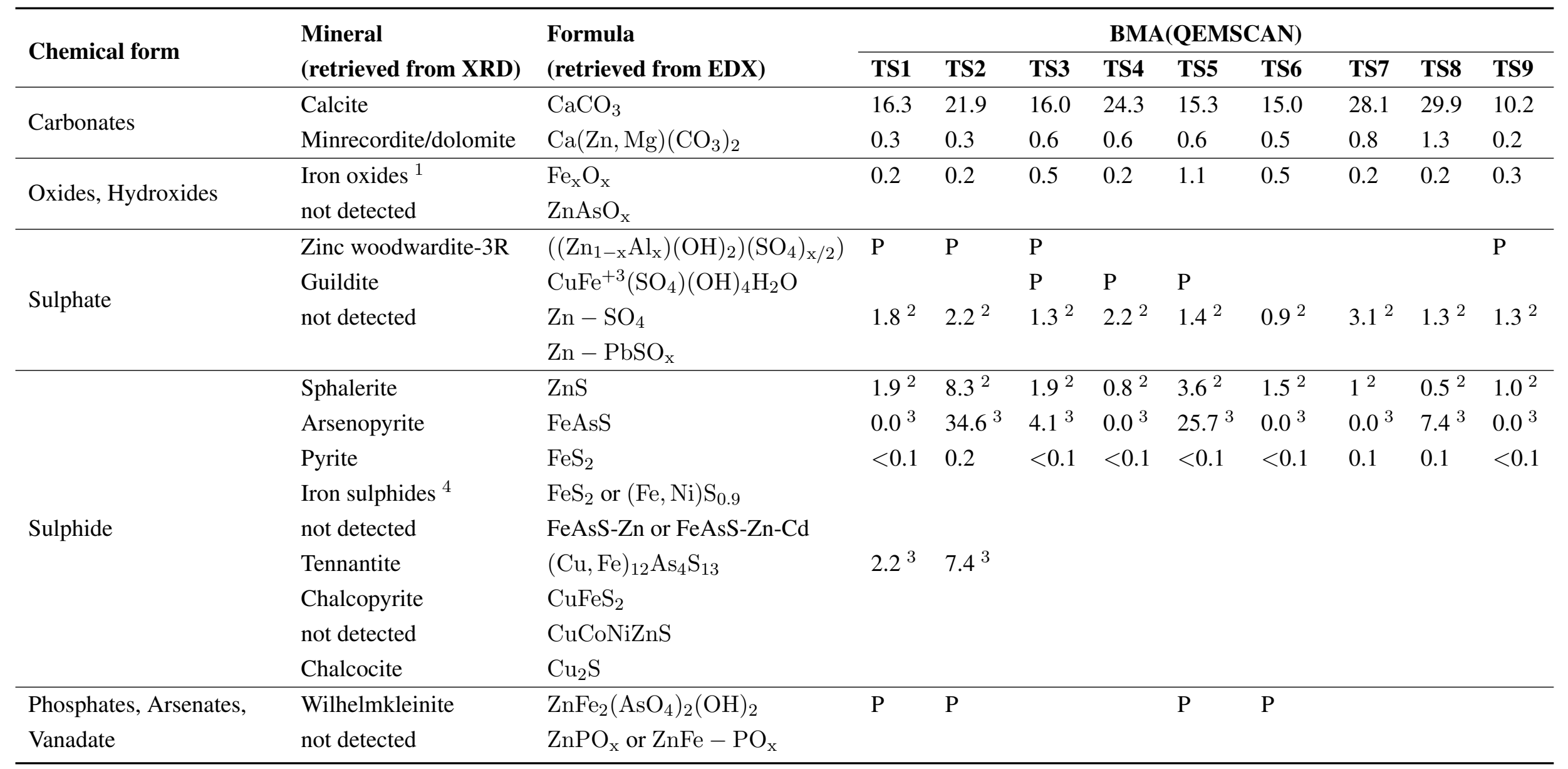

Notes: ${ }^{1}$ limonite, goethite, magnetite and hematite. ${ }^{2}$ the BMA values represent the percentage of this particle in the total of zinc-bearing minerals in the sample. ${ }^{3}$ the BMA values represent the percentage of this particle in the total of arsenic-bearing minerals in the sample. ${ }^{4}$ marcasite, mackinawite. $\mathrm{P}$ indicates that the particle was present, but not quantified. 
Figure 2. Backscattered electron microscopy photomicrographs of zinc-arsenic sulphides on the surface of (a) amphibole and (c) feldspar and one example EDX spectrum ((b) and (d)) from the bright mineral phase around the outside of the amphibole or feldspar (red arrow on the photomicrographs). The small white-boarded triangles indicate the positions where EDX spectra were obtained.

(a)

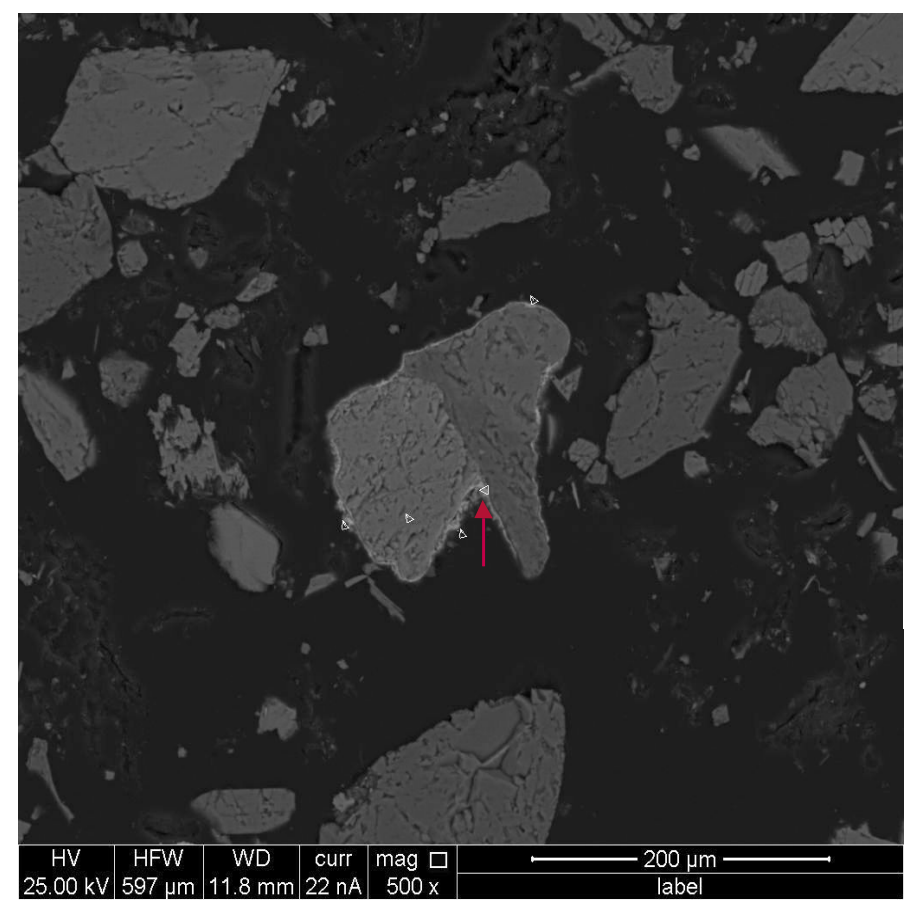

(c)

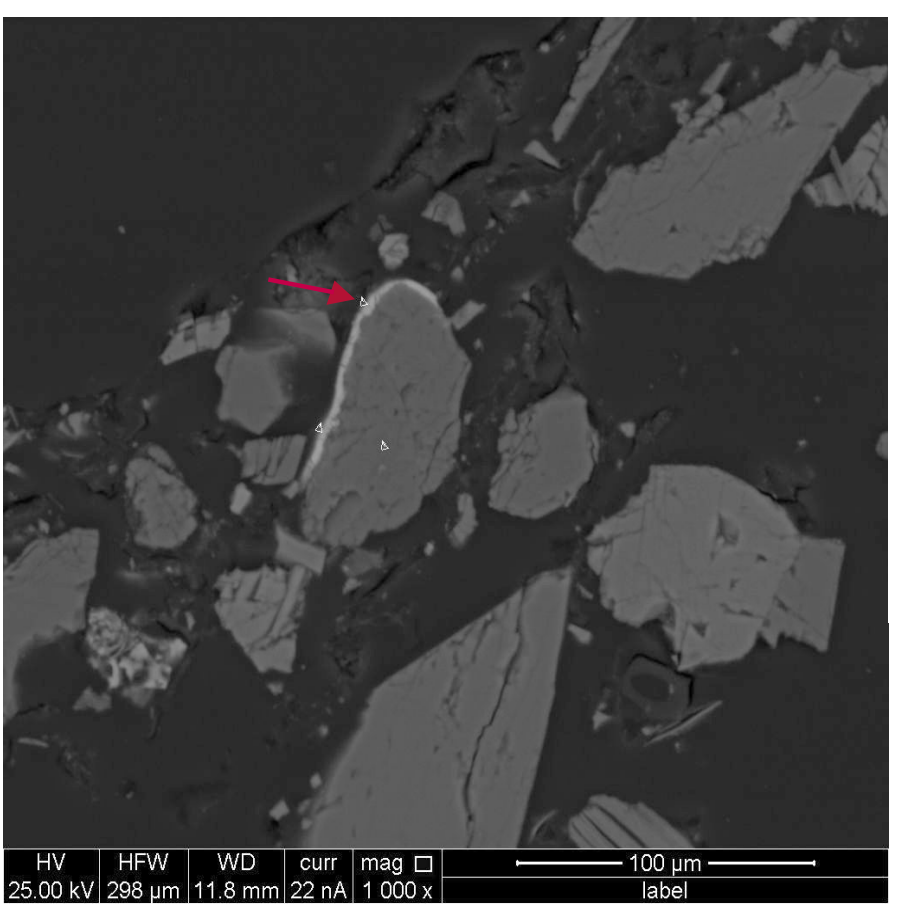

(b)

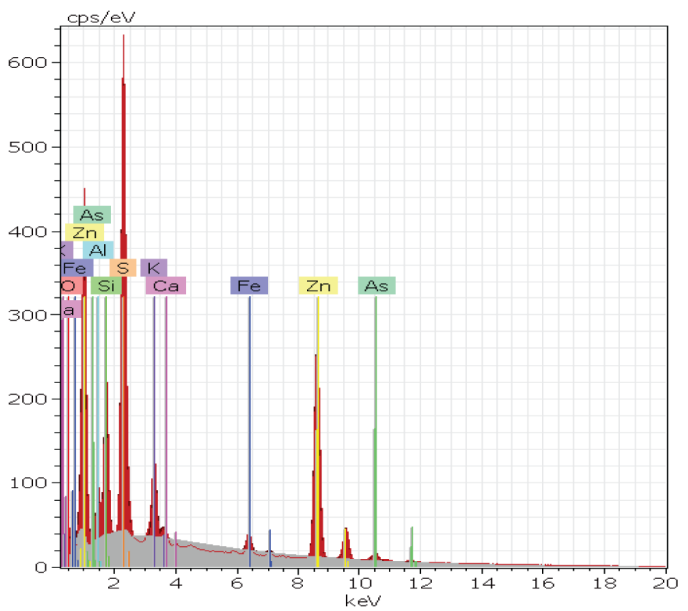

(d)

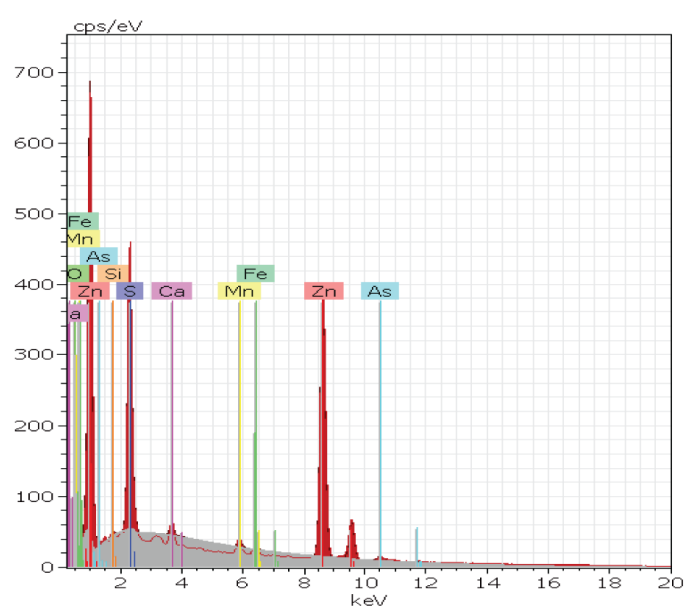


Figure 3. Backscattered electron microscopy photomicrographs and EDX spectra of some other mineral particles: (a) arsenic-zinc-iron- \pm cadmium-bearing particles; (b) EDX spectra for the point indicated by the red arrow in (a); (c) copper-iron-sulphide particles; (d) EDX spectra for the position indicated by the red arrow in (c); (e) zinc-phosphorus, metallic zinc and zinc-iron-sulphide particles; (f) EDX spectra for position indicated by the red arrow in (e); (g) arsenic-iron-zinc-oxide particle and (h) EDX spectra for the position indicated by the red arrow in $(\mathbf{g})$.

(a)

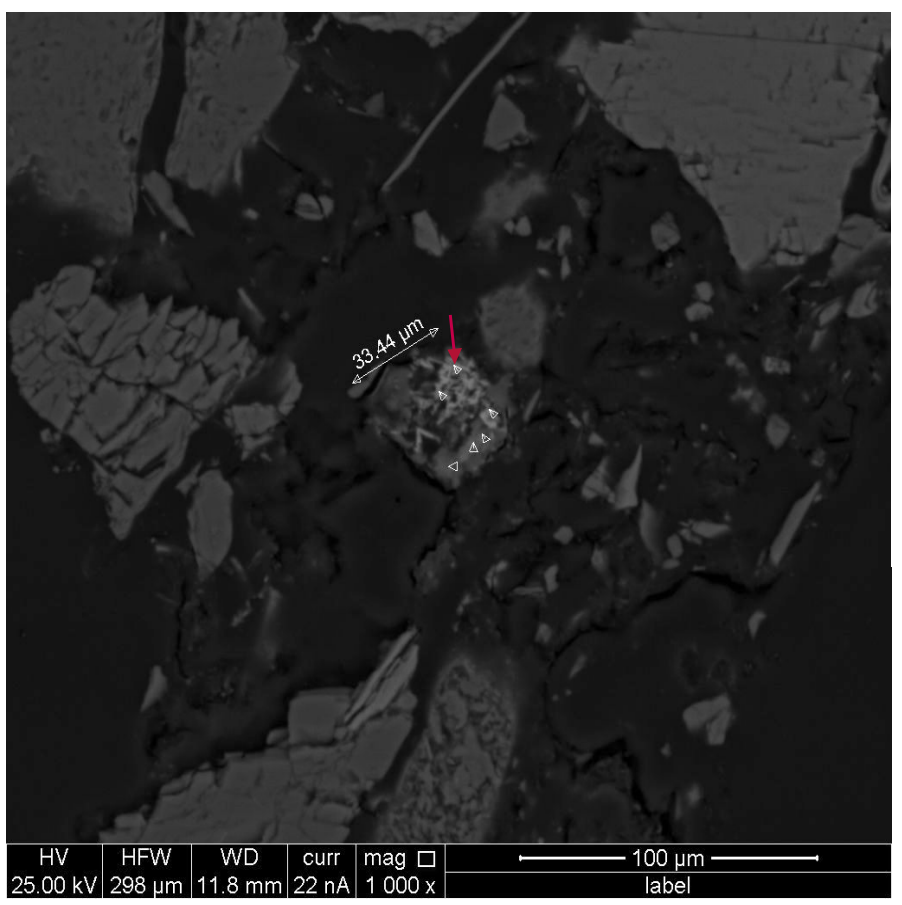

(c)

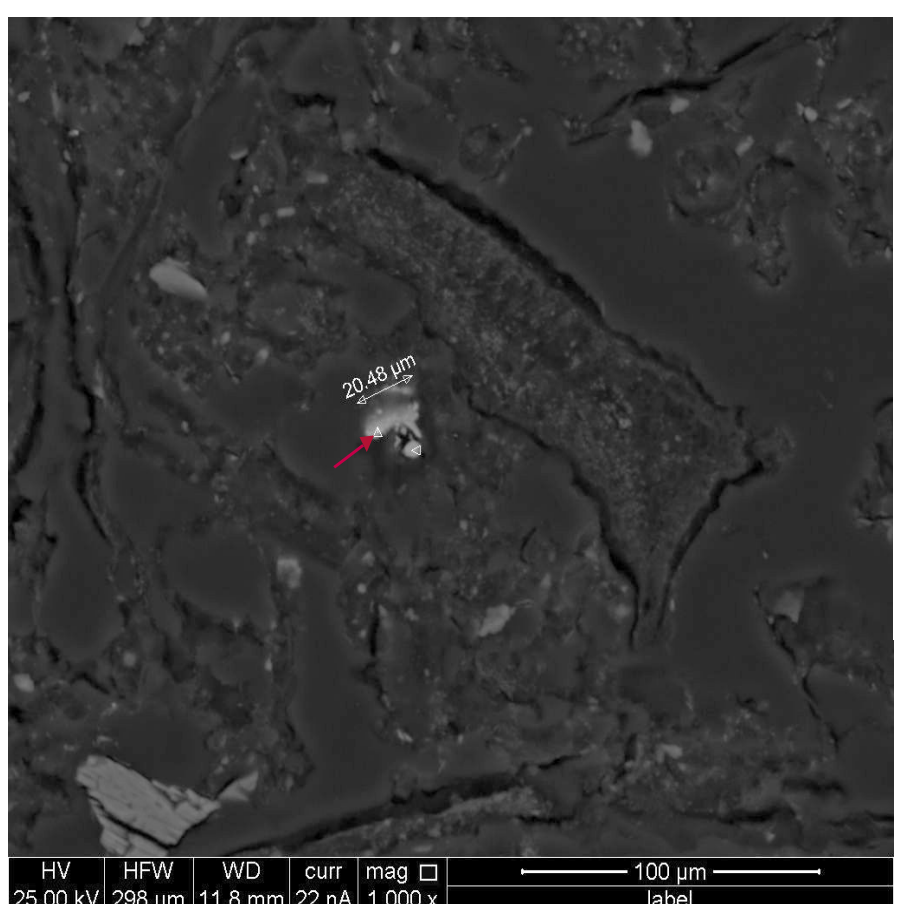

(b)

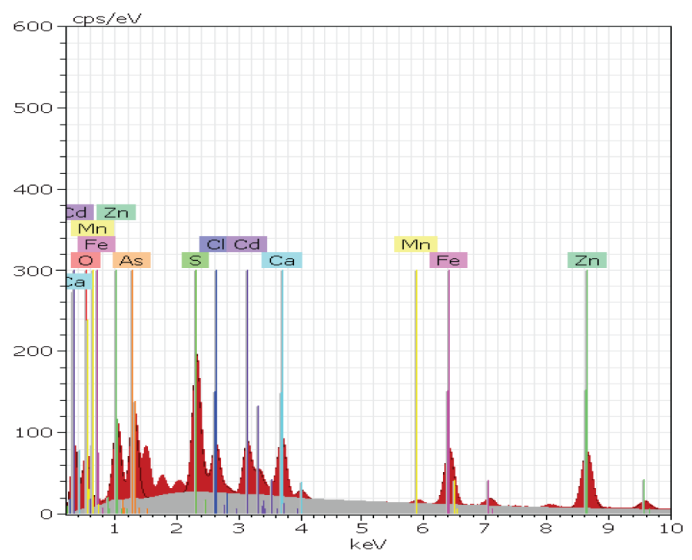

(d)

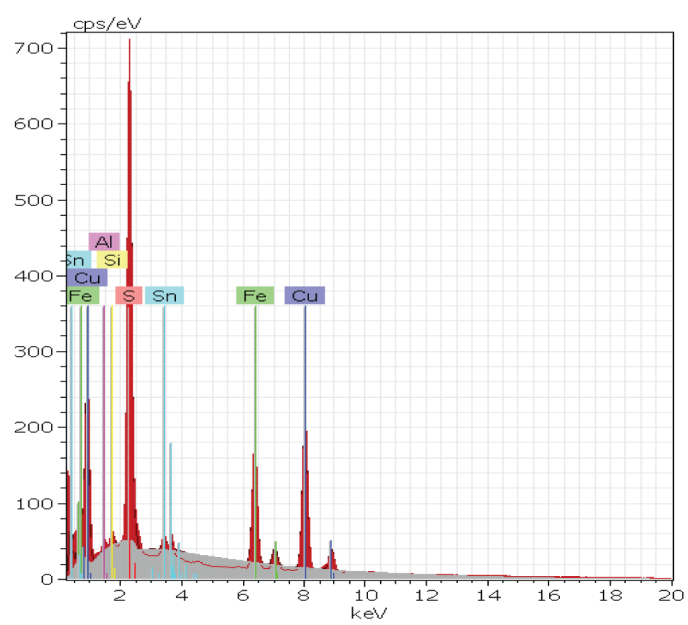


Figure 3. Cont.

(e)

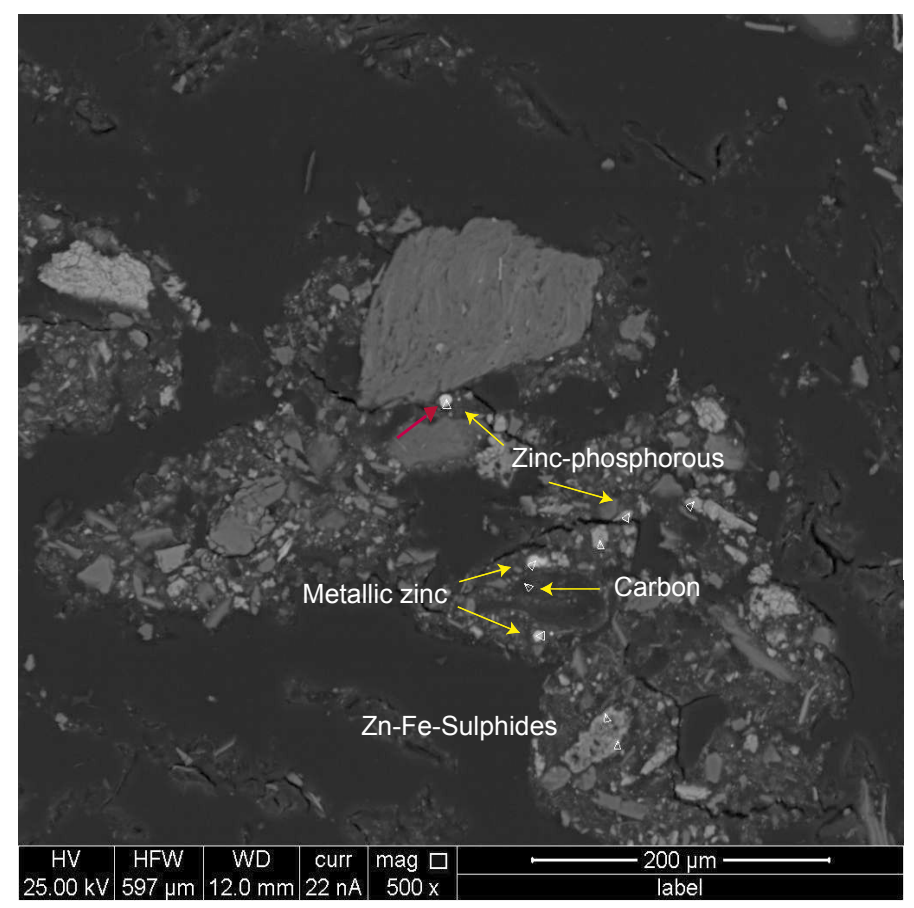

(g)

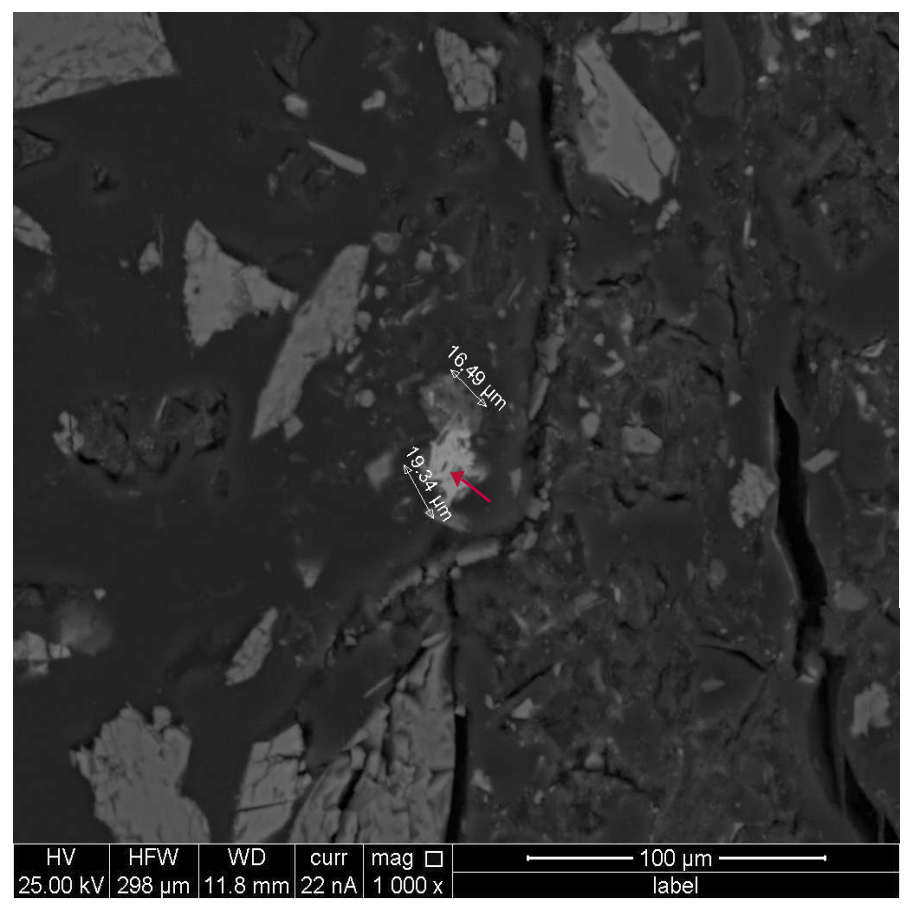

(f)

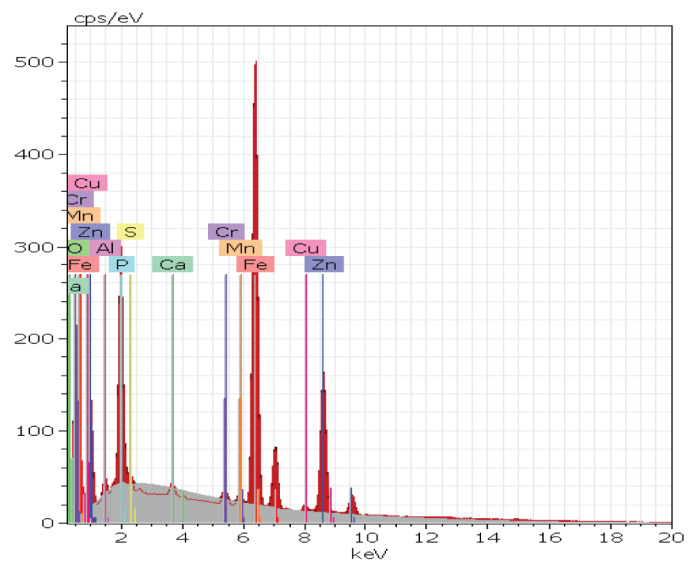

(h)

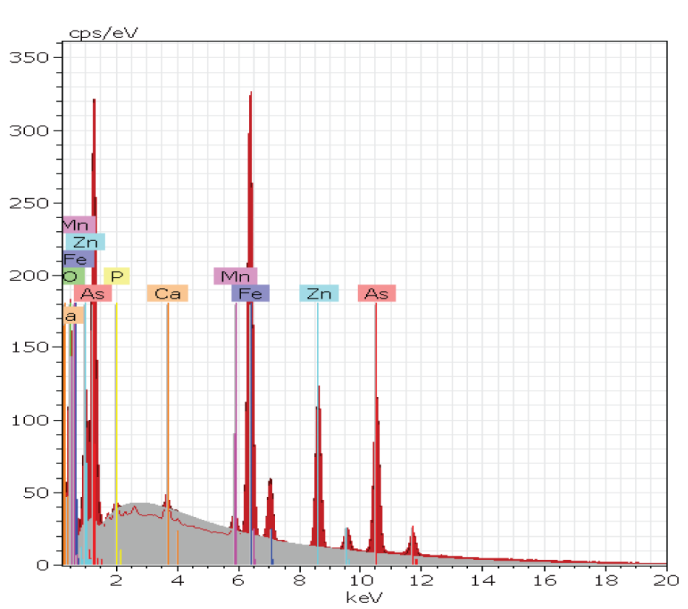

Zinc-arsenic sulphosalts/sulphates, particularly sulphides, were relatively predominant in the samples compared to other minerals identified with QEMSCAN analysis: sphalerite was a common mineral observed in many of the samples, either as liberated sphalerite particles (zinc and sulphur spectra solely detected) or in association with other particles, such as iron oxides or silicate minerals. An interesting observation was the coating of sphalerite $(24.5 \%-26.3 \% \mathrm{Zn}$ and $12.6 \%-15 \% \mathrm{~S})$ on amphibole 
(Figure 2a). The X-ray analysis revealed that As was also present in this mineral phase up to 2.2\%. Similarly, Figure 2c shows a feldspar particle with a bright coating present that contained zinc and sulphur at $36.1 \%$ and $14.7 \%$, respectively, that was also associated with arsenic (3.0\% As). An arsenic peak was absent from the point analysis spectra obtained from inside of the amphibole and feldspar particles, verifying arsenic's association with the sphalerite coating.

The QEMSCAN BMA reported arsenopyrite in some particles (Table 2), such as the one with an irregular shape and average diameter estimated at $33.44 \mu \mathrm{m}$ in Figure 3a. EDX spectra indicated high amounts of arsenic in this particle (2.6\%-21.8\%), as well as $\mathrm{Zn} \mathrm{(1.1 \% -29.4 \% ),} \mathrm{Fe} \mathrm{(1.5 \% -15.5 \% ),}$ $\mathrm{S}(0-6.2 \%)$ and, at some positions, cadmium (0-6\%). The composition of these elements varied throughout the particle, making it difficult to associate them with any one mineral type.

Copper-iron sulphosalts/sulphates were detected. One with $15.1 \% \mathrm{Cu}, 12.1 \% \mathrm{Fe}$ and $7.0 \% \mathrm{~S}$ is shown in Figure 3c. This particle was associated with an aggregate of irregular-shaped non-mineral phases and could represent chalcopyrite $\left(\mathrm{CuFeS}_{2}\right)$ or guildite $\left(\mathrm{CuFe}^{+3}\left(\mathrm{SO}_{4}\right)(\mathrm{OH})_{4} \mathrm{H}_{2} \mathrm{O}\right)$. Indeed, XRD and EDX analysis detected copper minerals, such as guildite, chalcopyrite, chalcocite and tennantite. There were some challenges with finding tennantite with XRD analysis, since the tennantite peak overlaps with other peaks. With QEMSCAN BMA analysis, only small amounts of guildite were present, but the arsenicbearing tennantite, $\left(\mathrm{Cu}_{11.9} \mathrm{Fe}_{0.1}\right) \mathrm{As}_{4} \mathrm{~S}_{13}$, was more prevalent at $2.2 \%$ and $7.4 \%$ of the arsenic-bearing minerals in samples TS1 and TS2, respectively (Table 2).

Zinc phosphate particles were also identified by PMA, as shown in Figure 3f, where the spectra clearly show phosphorus and zinc peaks (6.5\% and $16.3 \%$, respectively). One interesting observation was that metallic zinc particles $(64.9 \%-65.2 \% \mathrm{Zn})$ were present on the outside of a dark object composed of carbon, approximately $100 \mu \mathrm{m}$ long. In Figure 3f, zinc iron sulphides were also detected. QEMSCAN PMA identified arsenate oxide particles, such as wilhelmkleinite $\mathrm{ZnFe}_{2}\left(\mathrm{AsO}_{4}\right)_{2}(\mathrm{OH})_{2}$. Figure $3 \mathrm{~h}$ presents an example, where the bright phases are related to zinc, iron and arsenic peaks. The composition measured at one location was $10.8 \% \mathrm{Zn}, 15.2 \% \mathrm{Fe}$ and $23.9 \% \mathrm{~S}$, respectively. Wilhelmkleinite was identified also by XRD analysis and QEMSCAN BMA (Table 2).

\subsection{BCR Microbial Groups Possibly Associated with Metal Removal}

Comparison of the microbial community compositions of the core samples was based on their phylogenetic distances from each other, and they were clustered according to three principal coordinates. The two coordinates representing the most variation are presented in Figure 4, where the samples are coloured according to the amount of arsenic and zinc measured in the solids (values from Table 1). The microbial communities found in the high metal concentration samples cluster together towards the top left of the principal coordinate diagram, whereas those in the low metal concentration samples are grouped together towards the bottom right. The microbial groups more prevalent in the metal-rich samples (Figure 5) included the poorly characterized taxonomic groups of Bacteroidetes-related SB-1, VadinHA17 and M2PB4-65 environmental groups, candidate division WS6, RF3 and TM6, as well as the better known Synergistaceae family, Victivallales order and methanogen genera Methanocorpusculum, Methanospirillum and Methanosarcina. The number of sequences or reads binned into each OTU provides an indication of the prevalence of the organism from which those sequences came in the 
BCR samples (Table S6, Supplemental Information). The Methanospirillum-related OTU was the most highly represented followed by an OTU classified in the WS6 phylum and a M2PB4-65 termite group-related OTU.

Although not highly correlated with the high metal concentration samples, sequences related to sulphate-reducing and iron-reducing bacteria, especially those represented in the Deltaproteobacteria class, were detected in the core samples. The Deltaproteobacteria-related operational taxonomic units or OTUs (bins of sequences more than $97 \%$ homologous to each other) were classified into the orders of Bdellovibrionales, Desulfobacterales, Desulfovibrionales, Desulfuromonadales, Myxococcales and Syntrophobacterales and environmental clone groups GR-WP33-30, Sh765B-TzT-29 and Sva0485 or were unclassified sequences labelled as Incertae sedis (Table S7, Supplemental Information).

The most prevalent groups of putative sulphate-reducing bacteria (SRBs) identified in the BCR were classified into the orders Desulfovibrionales and Desulfobacterales (Table S7, Supplemental Information), which were most closely related to cultured species, Desulfobulbus elongatus strain FP, Desulfovibrio mexicanus strain Lup1, Desulfovibrio paquesii, Desulfovibrio aminophilus strain ALA-3 and Desulfovibrio idahonensis. The most prevalent Deltaproteobacteria-related OTUs were classified into the environmental group Sh765B-TzT-29 (40\% of all Deltaproteobacteria-related sequences). There were no cultured species closely related to the BCR Sh765B-TzT-29 OTUs. In addition to the Deltaproteobacteria-related OTUs, putative SRBs were classified in five genera in the Firmicutes phylum. Each OTU was rare (less than 10 reads per OTU), but the total number of sequences assigned to the Desulfosporosinus and Desulfotomaculum genera indicate that these SRB may have been important sulphate reducers in the BCR.

Figure 4. Microbial community principal coordinate analysis with arsenic and zinc concentrations coloured from blue (high) to red (low).

As

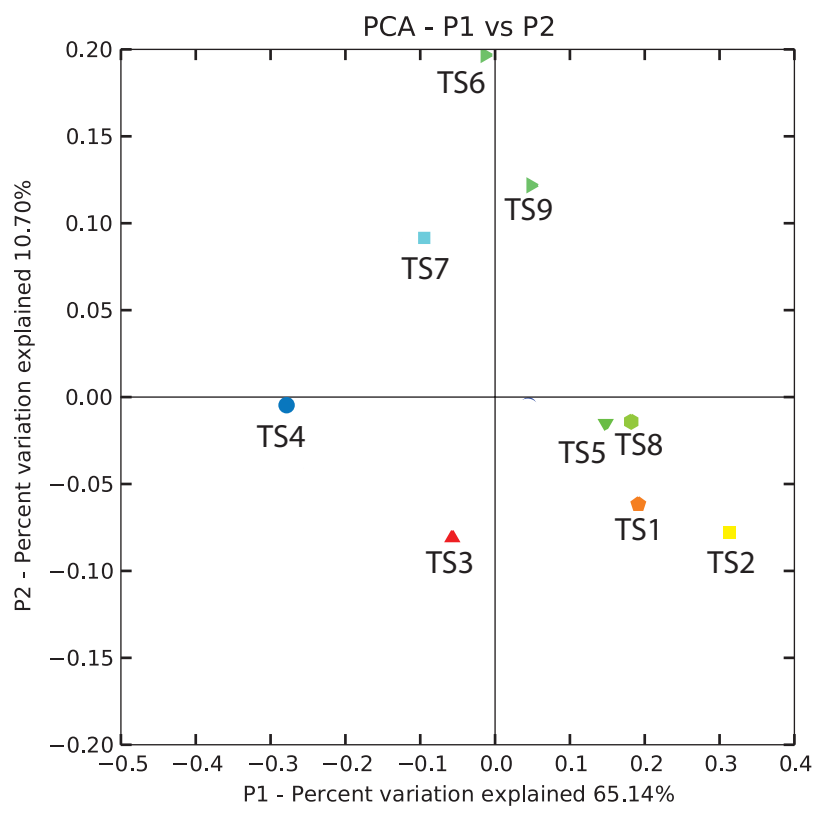

$\mathrm{Zn}$

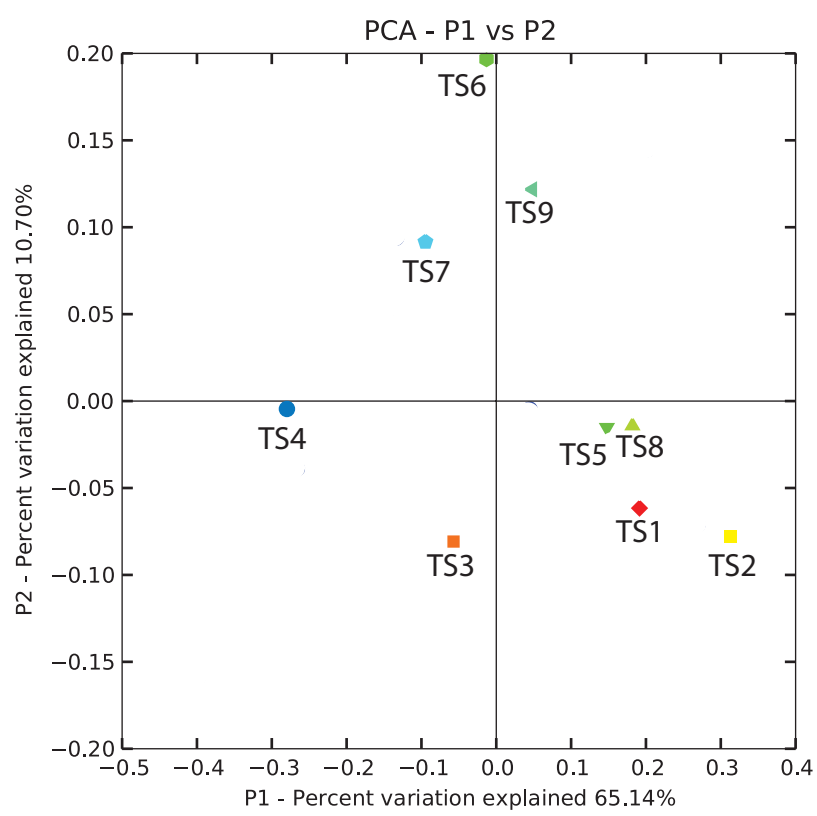


Figure 5. Microbial community principal coordinate analysis with highly correlated microbial groups coloured blue (high read count) to red (low read count).
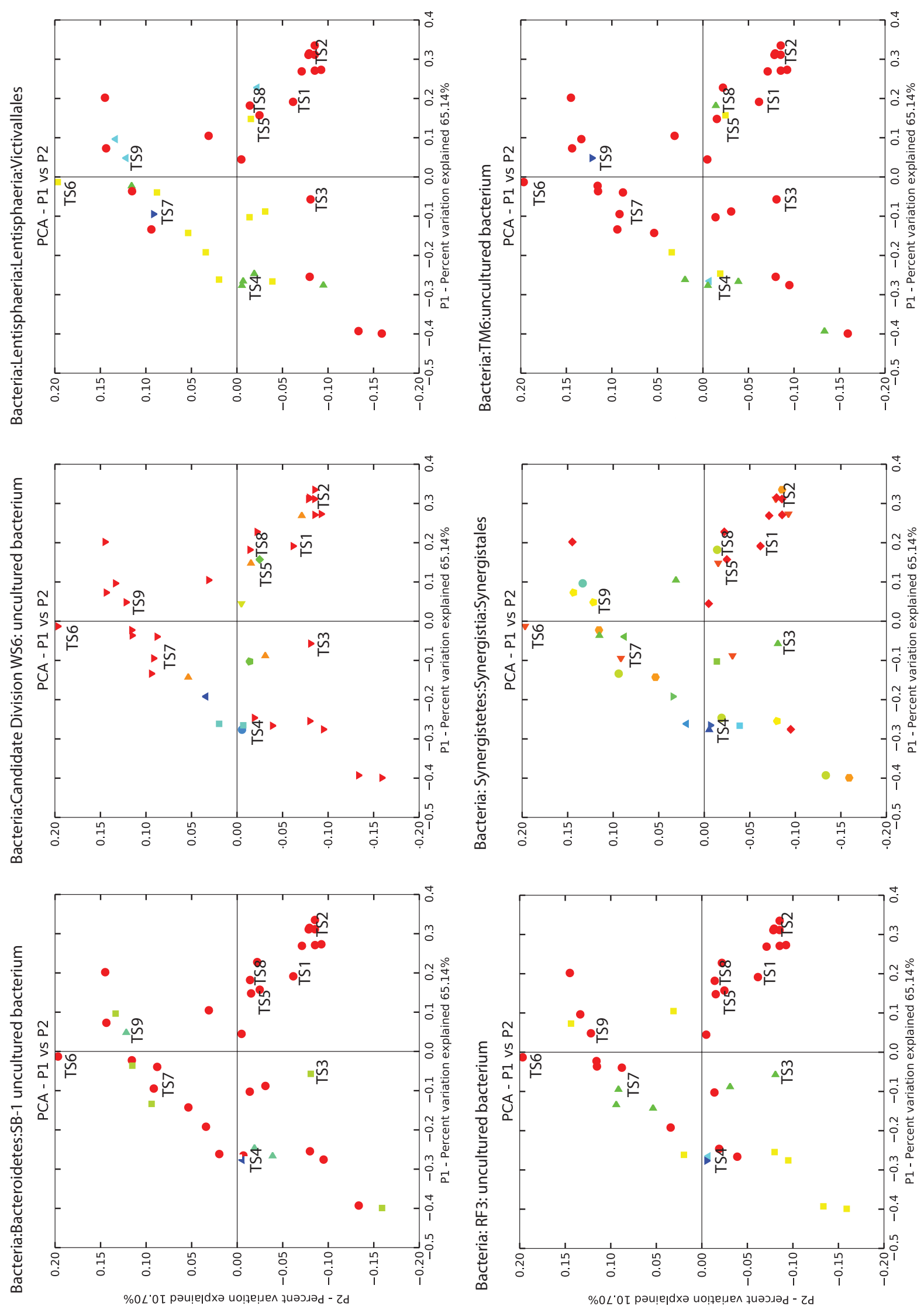
None of the BCR sequences were classified in genera of known iron-reducing bacteria, such as Shewanella or Geobacter. Very few sequences were classified as Thiobacillus and Acidithiobacillus. However, the BCR phylogeny indicated that many microbial groups were similar to those found previously in iron-reducing enrichments, such as Gracilibacter thermotolerans JW/YJL-S1 (97\% homology), Proteiniphilum acetatigenes (94\% homology), Bacteroides graminisolvens strain XDT-1 (97\% homology) and the anaerobic digester-related environmental clone, VadinBC27 (accession number U81676). However, all of the previously mentioned cultured species are fermentative, proteolytic or cellulose degraders, and none of them are known iron-reducers.

\section{Discussion}

Since dissolved arsenic and zinc concentrations decreased through the BCR, there is evidence that adsorption and mineralization were occurring and contributing to metal removal in addition to filtration of the incoming solid forms of arsenic and zinc. Köttigite that was detected in the BCR influent previously was not identified in any of the BCR core samples subjected to XRD in this study. One possibility could have been that all the köttigite was removed due to filtration deeper in the BCR near the inlet. Another explanation might be that köttigite was transformed to the closely related zinc-iron-arsenate mineral, Wilhelmkleinite, that was detected by XRD and QEMSCAM BMA. Nevertheless, it is not impossible that some of the solids entering the BCR could have dissolved and reformed as different mineral types. Arsenate-reducing bacteria were present in the BCR [41] and might have contributed to the release of arsenic from arsenate mineral forms.

The main drivers for mineralization in the BCR were the geochemical reducing conditions, processes mediated by microorganisms and adsorption to surfaces. It is not possible to determine definitively whether microbiological processes were direct or indirect, causal or incidental to mineralization. However, mineralogical forms were detected that were consistent with biological mechanisms playing a role together with geochemistry, as is discussed below.

\subsection{Evidence for Biotic Mineralization}

Minerals that are consistent with biomineralization processes were detected, namely sulphides and carbonates. Sphalerite was a common mineral observed in many of the samples, and the microbial community analysis of the BCR supports the hypothesis of a biological role in that SRBs were present and likely provided the source of sulphide. Biologically-induced ZnS (sphalerite) formation by SRBs has been demonstrated in other studies under laboratory conditions and in biofilms exposed to mine effluent $[22,23,42]$. Thus, the BCR was successful in creating environmental conditions for SRB to thrive.

The forms of arsenic sulphide found in the BCR were tennantite and arsenopyrite, the latter being the predominant form predicted by As-Fe-S-O-H geochemical modelling for high Fe conditions. This indicates that iron played an important role in arsenic removal in this system. The role that biology might have played to make the formation of arsenopyrite possible would be arsenate reduction to arsenite by dissimilatory arsenate-reducing prokaryotes and the reduction of sulphate to sulphide by SRB, since both microbial groups were identified in the BCR. Arsenite may have adsorbed to pre-existing iron 
sulphides to form arsenopyrite. Arsenic adsorption to solids is the major mechanism responsible for reducing aqueous arsenic concentrations in natural soils and sediments [43]. Arsenite sorbs strongly to iron sulphides, pyrite $\left(\mathrm{FeS}_{2}\right)$ and pyrrhotite $(\mathrm{FeS})$, especially at circumneutral pH [44]. X-ray absorption spectroscopy of iron sulphides that had been reacted with arsenic revealed that As on the mineral surface was coordinated with both Fe and S, demonstrating the formation of arsenopyrite [44]. Iron sulphides were present in the BCR; therefore, such a mechanism for arsenopyrite formation was possible. According to geochemical predictions, conditions in the BCR were favorable for the formation of other arsenic sulphides (realgar or orpiment) under conditions of low Fe (Figure S2, Supplemental Information), but neither of these As minerals were observed in our samples. In laboratory SRB reactors, realgar and orpiment were the predominant arsenic precipitates at low $\mathrm{pH}$, which was attributed to the presence of acid-tolerant SRB, such as those of the Desulfosporosinus genus [45]. Sequences closely related to these SRB were also found in the BCR core samples.

In summary, the microbial activities of many groups in the BCR played indirect roles in mineralization by consuming all the oxygen entering with the influent and creating a reducing environment, as well as by increasing alkalinity through carbonate formation, which raised the $\mathrm{pH}$. Combined with biogenic sulphide formation, this provided favorable geochemical conditions for metal sulphide precipitation.

Carbonates could have formed during treatment. Both dolomite $\mathrm{CaMg}\left(\mathrm{CO}_{3}\right)_{2}$ and minrecordite $\mathrm{CaZn}\left(\mathrm{CO}_{3}\right)_{2}$ were detected in the BCR samples and could have been mineralogical sinks for some of the $\mathrm{Zn}$ removed during treatment. As dolomite is formed, $\mathrm{Zn}$ could substitute for $\mathrm{Mg}$ forming minrecordite. Furthermore, solid solution from $\mathrm{Mg}$-dolomite, $\mathrm{CaMg}\left(\mathrm{CO}_{3}\right)_{2}$, towards $\mathrm{Zn}$-dolomite is possible [46]. $\mathrm{Zn}$-dolomite has been identified as a secondary mineral in wastes associated with historical $\mathrm{Zn}-\mathrm{Pb}$ ore mining [47]. Microbiologically-mediated dolomite formation has been shown to occur in anaerobic sediments and in laboratory experiments, where sulphate-reducing bacteria were found to play a specific role in the formation of the dolomite $[48,49]$. Thus, it is feasible for carbonate formation to be another biologically-mediated mineralization mechanism for $\mathrm{Zn}$ in the BCR.

Microorganisms, such as Synergistetes, that were highly correlated with metal content suggest a role for these microbes in mineralization, although there are no studies available supporting their bioprecipitation of arsenic and zinc. The most closely related cultured species was Thermanaerovibrio acidaminovorans (90\% homology), which is a thermophilic amino acid fermenter, which was the first member of the Synergistetes phylum to to have its complete genome sequenced [50]. The Synergistetes-related BCR sequences were distantly related to the species, Dethiosulfovibrio peptidovorans, which has been associated with metal interactions, such as corrosion of steel in oil wells [51], and closely related clones were prevalent in copper-polluted sediment in Chile [52]. Dethiosulfovibrio peptidovorans are strictly anaerobic and known to reduce thiosulphate and might be important for metal sulphide precipitation.

\subsection{Other Possible Mechanisms for Mineral Formation in the BCR}

Textural association of $\mathrm{Zn}$ - and As-bearing minerals with other particles, as revealed with the QEMSCAM PMA imaging, suggested that adsorption and co-precipitation may have contributed to immobilization of arsenic and zinc in the BCR. This was observed on feldspar and amphibole (Figure 2c), 
where a bright coating was related to sphalerite with trace amounts of arsenic. The feldspars and amphibole, which are silicate minerals, were prevalent in the samples, due to the limestone that was included in the BCR matrix. In fact, feldspar has been used for the treatment of arsenite(III) in other studies, where a maximum adsorption of $90.19 \%$ was obtained [53]. Clay minerals, such as illite, kaolinite [54] and mullite [55], have been used for arsenate adsorption [56]. Kaolinite was present at $0.3 \%$ in some of the BCR samples; however, adsorption of As or $\mathrm{Zn}$ was not detected on these minerals.

Oxy-hydroxides, which were found in the BCR solids (such as those of Fe(III), Mn(III,IV) and $\mathrm{Al}(\mathrm{III})$ ), are adsorbents for metal cations [57] and arsenic [58], most often under oxidative conditions. For example, removal of $\mathrm{As}(\mathrm{V})$ from solution by adsorption to iron oxy-hyroxides has been demonstrated in mine tailings at a uranium mine, where poorly crystalline scorodite was precipitated below $\mathrm{pH} 3$ [59]. In many cases, anaerobic conditions lead to resolubilization of iron, due to bacterially enhanced iron reduction to $\mathrm{Fe}(\mathrm{II})$, concomitant with As release [60]. Nevertheless, bacterial formation of Fe oxy-hydroxides is possible under anoxic conditions with nitrate as the electron acceptor for iron oxidizing bacteria, and one such microbe was isolated from the BCR [61]. Although evidence of arsenic or zinc adsorption on iron oxide particles was not observed in the samples used for this study, iron oxides, such as magnetite, were present, and in one case, particle X-ray analysis found magnetite adjacent to sphalerite. Therefore, it is possible for metal adsorption on iron oxy-hydroxides to occur inside the BCR.

Moreover, organic matter is also known to affect metal mobility in that degradation products, such as humic and fulvic acids, strongly adsorb arsenic at near neutral $\mathrm{pH}$, for example [57,58]. The pulp mill biosolids used in the BCR matrix (65 wt \% of the starting material) could have been a potent adsorbent for metal cations. Although the organics had been removed from the samples, rare elements were found that were associated with complex particles and aggregates, possibly remnants of organic material. However, adsorption sites reach saturation relatively soon after start-up in these types of bioreactors. Mattes estimated from the total mass of biosolids used in the BCR that all adsorption sites would be occupied within the first four months of operation [62]. This suggests that adsorption is not a reliable mechanism for long-term metal removal in these systems.

\section{Conclusions}

A comprehensive mineralogical assessment using X-ray diffraction (XRD) and quantitative evaluation of minerals by scanning electron microscopy (QEMSCAN) was performed to identify arsenic- and zinc-bearing minerals in a biochemical reactor treating metal-rich leachate, so as to gain new insights into the chemical and biological processes that mediate metal removal. Identification of these arsenic- and zinc-bearing minerals was very challenging, due to their rarity in the mostly organic-rich matrix, and was overcome through a low temperature ash pretreatment. A hybrid particle QEMSCAN analysis (PMA) proved to be an effective approach to find trace and low abundant arsenic- and zinc-bearing minerals. Many mechanisms, both biotic and abiotic, were involved in the mineralization of arsenic and zinc as oxides, sulphides, sulphates and phosphates. The evidence of arsenic and zinc-bearing minerals coating amphibole and feldspar particles suggested that adsorption followed by precipitation. QEMSCAM BMA indicated that zinc and arsenic sulphides were predominant forms, which were attributed to the presence 
of SRB verified by the presence of sequences related to known SRB found together with the precipitates. Inclusion of zinc in carbonates was another possible biologically-mediated mechanism.

Particular groups of microbes were highly correlated with metal-rich samples. Some of these were taxonomically classified in uncharacterized novel phyla of environmental sequences. These organisms may play some as yet unknown role in metal precipitation. Sequences classified in the Synergistetes phylum were prevalent and strongly correlated with metal-rich samples. Some members of this phylum are thiosulphate-reducing and could potentially play a role in metal sulphide formation.

\section{Acknowledgments}

The authors would like to acknowledge Mount Polley Mine, Teck Mining Company, NatureWorks Remediation Corporation, Genome British Columbia and the Natural Sciences and Engineering Research Council of Canada for providing funding for this research. The Teck Applied Research and Technology personnel are acknowledged for their assistance with the water chemical analysis. Much appreciation goes to Xiaowen (Wendy) Ma at ALS Metallurgy and Jenny Lai at the Electron Microbeam/X-Ray Diffraction Facility, University of British Columbia. The authors are very grateful for the extensive assistance received from Al Mattes of NatureWorks Remediation Corporation and the late Jimmy Hall of Impact Equipment during sample collection. The three anonymous reviewers are thanked for their insightful comments and recommendations, which contributed to the improvements in the paper.

\section{Conflicts of Interest}

The authors declare no conflict of interest.

\section{References}

1. Wieder, R.K. A survey of constructed wetlands for acid coal mine drainage treatment in the Eastern United States. Wetlands 1989, 9, 299-315.

2. Gusek, J.J.; Gormley, J.T.; Scheetz, J.W. Design and construction aspects of pilot-scale passive treatment systems for acid rock drainage at metal mines. Hydrometallurgy '94 1994, 1994, 777-793.

3. Larratt, H.; Freburg, M.; Hamaguchi, R. Developing Tailings Ponds and Pit Lakes as Bioreactors and Habitat Cost-Effective Successes at Highland Valley Copper. In British Columbia's 31st Annual Mine Reclamation Symposium; The British Columbia Technical and Research Committee on Reclamation (TRCR): Squamish, Canada, 2007.

4. Reisman, D.; Ruttcowski, T.; Smart, P.; Gusek, J.J. The Construction and Instrumentation of a Pilot Treatment System at the Standard Mine Superfund Site, Crested Butte, CO. In Proceedings of the 2008 National Meeting of the American Society of Mining and Reclamation, Richmond, VA, USA, 14-19 June 2008.

5. Mattes, A.; Evans, L.J.; Douglas Gould, W.; Duncan, W.F.A.; Glasauer, S. The long term operation of a biologically based treatment system that removes As, S and $\mathrm{Zn}$ from industrial (smelter operation) landfill seepage. Appl. Geochem. 2011, 26, 1886-1896. 
6. Blumenstein, E.P.; Gusek, J.J. Designing a Biochemical Reactor for Selenium and Thallium Removal, from Bench Scale Testing Through Pilot Construction. In Hydrometallurgy 2008: Proceedings of the Sixth International Symposium; Young Taylor, P.R., Anderson, C.G., Choi, Y., Eds.; Society for Mining, Metallurgy, Exploration: Phoenix, AZ, USA, 2008; pp. 117-129.

7. Dann, A.L.; Cooper, R.S.; Bowman, J.P. Investigation and optimization of a passively operated compost-based system for remediation of acidic, highly iron- and sulfate-rich industrial waste water. Water Res. 2009, 43, 2302-2316.

8. Dvorak, D.H.; Hedin, R.S.; Edenborn, H.M.; McIntire, P.E. Treatment of metal-contaminated water using bacterial sulfate reduction: Results from pilot-scale reactors. Biotechnol. Bioeng. 1992, 40, 609-616.

9. Hammack, R.W.; Edenborn, H.M.; Dvorak, D.H. Treatment of water from an open-pit copper mine using biogenic sulfide and limestone: A feasibility study. Water Res. 1994, 28, 2321-2329.

10. Winch, S.; Mills, H.J.; Kostka, J.E.; Fortin, D.; Lean, D.R.S. Identification of sulfate-reducing bacteria in methylmercury-contaminated mine tailings by analysis of SSU rRNA genes. FEMS Microbiol. Ecol. 2009, 68, 94-107.

11. Regine, H.S.F.; Vieira, S.F.; Volesky, B. Biosorption: A solution to pollution. Int. Microbiol. 2000, $3,17-24$.

12. Churakov, S.V.; Dähn, R. Zinc adsorption on clays inferred from atomistic simulations and EXAFS spectroscopy. Environ. Sci. Technol. 2012, 46, 5713-5719.

13. Fortin, D.; Southam, G.; Beveridge, T.J. Nickel sulfide, iron-nickel sulfide and iron sulfide precipitation by a newly isolated Desulfotomaculum species and its relation to nickel resistance. FEMS Microbiol. Ecol. 1994, 14, 121-132.

14. Bridge, T.A.; White, C.; Gadd, G.M. Extracellular metal-binding activity of the sulphate-reducing bacterium Desulfococcus multivorans. Microbiology 1999, 145, 2987-2995.

15. Frankel, R.B. Biologically induced mineralization by bacteria. Rev. Mineral. Geochem. 2003, $54,95-114$.

16. Glasauer, S.; Langley, S.; Beveridge, T.J. Sorption of Fe (hydr)oxides to the surface of Shewanella putrefaciens: Cell-bound fine-grained minerals are not always formed de novo. Appl. Environ. Microbiol. 2001, 67, 5544-5550.

17. Amoozegar, M.A.; Khoshnoodi, M.; Didari, M.; Hamedi, J.; Ventosa, A.; Baldwin, S.A. Tellurite removal by a tellurium-tolerant halophilic bacterial strain, Thermoactinomyces sp. QS-2006. Ann. Microbiol. 2012, 62, 1031-1037.

18. Fortin, D.; Praharaj, T. Role of microbial activity in Fe and $\mathrm{S}$ cycling in sub-Oxic to anoxic aulfide-rich mine tailings: A mini-review. J. Nucl. Radiochem. Sci. 2005, 6, 39-42.

19. Jiang, S.; Lee, J.H.; Kim, D.; Kanaly, R.A.; Kim, M.G.; Hur, H.G. Differential arsenic mobilization from As-bearing ferrihydrite by iron-respiring Shewanella strains with different arsenic-reducing activities. Environ. Sci. Technol. 2013, 47, 8616-8623.

20. Tufano, K.J.; Reyes, C.; Saltikov, C.W.; Fendorf, S. Reductive processes controlling arsenic retention: Revealing the relative importance of iron and arsenic reduction. Environ. Sci. Technol. 2008, 42, 8283-8289. 
21. Kocar, B.D.; Herbel, M.J.; Tufano, K.J.; Fendorf, S. Contrasting effects of dissimilatory iron(III) and $\operatorname{arsenic}(\mathrm{V})$ reduction on arsenic retention and transport. Environ. Sci. Technol 2006, 40, 6715-6721.

22. Labrenz, M.; Druschel, G.K.; Thomsen-Ebert, T.; Gilbert, B.; Welch, S.A.; Kemner, K.M.; Logan, G.A.; Summons, R.E.; Stasio, G.D.; Bond, P.L.; et al. Formation of sphalerite (ZnS) deposits in natural biofilms of sulfate-reducing bacteria. Science 2000, 290, 1744-1747.

23. Moreau, J.W.; Webb, R.I.; Banfield, J.F. Ultrastructure, aggregation-state, and crystal growth of biogenic nanocrystalline sphalerite and wurtzite. Am. Mineral. 2004, 89, 950-960.

24. Castillo, J.; Perez-Lopez, R.; Caraballo, M.A.; Nieto, J.M.; Martins, M.; Costa, M.C.; Olias, M.; Ceron, J.C.; Tucoulou, R. Biologically-induced precipitation of sphalerite-wurtzite nanoparticles by sulfate-reducing bacteria: Implications for acid mine drainage treatment. Sci. Total Environ. 2012, 423, 176-184.

25. Niggemyer, A.; Spring, S.; Stackebrandt, E.; Rosenzweig, R.F. Isolation and characterization of a novel As(V)-reducing bacterium: Implications for arsenic mobilization and the genus Desulfitobacterium. Appl. Environ. Microbiol. 2001, 67, 5568-5580.

26. Santini, J.M.; Sly, L.I.; Wen, A.; Comrie, D.; Wulf-Durand, P.D.; Macy, J.M. New arsenite-oxidizing bacteria isolated from Australian gold mining environments-Phylogenetic relationships. Geomicrobiol. J. 2002, 19, 67-76.

27. Jackson, C.K.; Koch, I.; Reimer, K.J. Mechanisms of dissolved arsenic removal by biochemical reactors: A bench- and field-scale study. Appl. Geochem. 2013, 29, 174-181.

28. Pirrie, D.; Butcher, A.R.; Power, M.R.; Gottlieb, P.; Miller, G.L. Rapid quantitative mineral and phase analysis using automated scanning electron microscopy (QemSCAN); Potential applications in forensic geoscience. Geol. Soc. 2004, 232, 123-136.

29. Baldwin, S.A.; Rezadehbashi, M.; Taupp, M.; Mattes, A.; Hallam, S.J. The Genetic Diversity of Microbes in a Biochemical Reactor Treating Metal-Rich Landfill Leachate: What This Tells Us about Treatment Mechanisms. In Proceedings of 9th International Conference on Acid Rock Drainage, Ottawa, Canada, 20-24 May 2012.

30. Adegoroye, A.; Uhlik, P.; Omotoso, O.; Xu, Z.; Masliyah, J. A comprehensive analysis of organic matter removal from clay-sized minerals extracted from oil sands using low temperature ashing and hydrogen peroxide. Energy Fuels 2009, 23, 3716-3720.

31. Buckwalter-Davis, M.; Jaggardi, H.; Morman, S.; Plumlee, G.; Jamieson, H. Using automated mineralogy to evaluate bioaccessibility of Pb-bearing mine waste. Mineral. Mag. 2012, 76, 1524.

32. Chemical Equilibrium Diagrams. Available online: http://www.kth.se/che/medusa/ (accessed on 10 December 2013).

33. Puigdomenech, I. MEDUSA: Make Equilibrium Diagrams Using Sophisticated Algorithms Programs; Royal Institute of Technology (KTH): Stockholm, Sweden, 2002.

34. Puigdomenech, I. HYDRA: Hydrochemical Equilibrium-Constant Database Software; Royal Institute of Technology (KTH): Stockholm, Sweden, 2004.

35. Lu, P.; Zhu, C. Arsenic Eh-pH diagrams at $25{ }^{\circ} \mathrm{C}$ and 1 bar. Environ. Earth Sci. 2010, 62, 1673-1683. 
36. Rezadehbashi, M.; Khoshnoodi, M.; Taupp, M.; Hallam, S.; Baldwin, S.A. Microbial Diversity of A Biochemical Reactor Removing Metals from Smelter Waste Leachate. In Proceedings of the 2012 Canadian Society of Microbiologists Annual Conference, Vancouver, Canada, 20-23 June 2012.

37. Quast, C.; Pruesse, E.; Yilmaz, P.; Gerken, J.; Schweer, T.; Yarza, P.; Peplies, J.; Glockner, F.O. The SILVA ribosomal RNA gene database project: Improved data processing and web-based tools. Nucleic Acids Res. 2013, 41, D590-D596.

38. Pruitt, K.D.; Tatusova, T.; Brown, G.R.; Maglott, D.R. NCBI Reference Sequences (RefSeq): Current status, new features and genome annotation policy. Nucleic Acids Res. 2012, 40, D130-D135.

39. Lozupone, C.; Knight, R. UniFrac: A new phylogenetic method for comparing microbial communities. Appl. Environ. Microbiol. 2005, 71, 8228-8235.

40. Caporaso, J.G.; Kuczynski, J.; Stombaugh, J.; Bittinger, K.; Bushman, F.D.; Costello, E.K.; Fierer, N.; Pena, A.G.; Goodrich, J.K.; Gordon, J.I.; et al. QIIME allows analysis of high-throughput community sequencing data. Nat. Methods 2010, 7, 335-336.

41. Khoshnoodi, M.; Taupp, M.; Mewis, K.; Hallam, S.; Baldwin, S.A. Screening for Arsenate and Arsenite Resistant Microbes in Passive Treatment Systems for Metal Leachate Remediation. In Proceedings of the 9th International Conference on Acid Rock Drainage, Ottawa, Canada, 20-24 May 2012.

42. Baas Becking, L.G.M.; Moore, D. Biogenic sulfides. Econ. Geol. 1961, 56, 259-272.

43. Wang, S.; Mulligan, C.N. Natural attenuation processes for remediation of arsenic contaminated soils and groundwater. J. Hazard. Mater. 2006, 138, 459-470.

44. Bostick, B.C.; Fendorf, S. Arsenite sorption on troilite $(\mathrm{FeS})$ and pyrite $\left(\mathrm{FeS}_{2}\right)$. Geochim. Cosmochim. Acta 2003, 67, 909-921.

45. Battaglia-Brunet, F.; Crouzet, C.; Burnol, A.; Coulon, S.; Morin, D.; Joulian, C. Precipitation of arsenic sulphide from acidic water in a fixed-film bioreactor. Water Res. 2012, 46, 3923-3933.

46. Rosenberg, P.E.; Foit, F.F. The stability of transition metal dolomites in carbonate systems: A discussion. Geochem. Cosmochim. Acta 1979, 43, 951-955.

47. Cabala, J.; Zogala, B.; Dubiel, R. Geochemical and geophysical study of historical Zn-Pb ore processing waste dump areas (Southern Poland). Polish. J. Environ. Stud. 2008, 17, 693-700.

48. Vasconcelos, C.; McKenzie, J.A.; Bernasconi, S.; Grujic, D.; Tiens, A.J. Microbial mediation as a possible mechanism for natural dolomite formation at low temperatures. Nature 1995, 377, 220-222.

49. Warthmann, R.; van Lith, Y.; Vasconcelos, C.; McKenzie, J.A.; Karpoff, A.M. Bacterially induced dolomite precipitation in anoxic culture experiments. Geology 2000, 28, 1091-1094.

50. Chovatia, M.; Sikorski, J.; Schroder, M.; Lapidus, A.; Nolan, M.; Tice, H.; Glavina Del Rio, T.; Copeland, A.; Cheng, J.F.; Lucas, S.; et al. Complete genome sequence of Thermanaerovibrio acidaminovorans type strain $\left(\mathrm{Su} 883^{\mathrm{T}}\right)$. Stand. Genomic Sci. 2009, 1, 254-261. 
51. Labutti, K.; Mayilraj, S.; Clum, A.; Lucas, S.; Glavina Del Rio, T.; Nolan, M.; Tice, H.; Cheng, J.F.; Pitluck, S.; Liolios, K.; et al. Permanent draft genome sequence of Dethiosulfovibrio peptidovorans type strain (SEBR 4207T). Stand. Genomic Sci. 2010, 3, 85-92.

52. Pavissich, J.P.; Silva, M.; González, B. Sulfate reduction, molecular diversity, and copper amendment effects in bacterial communities enriched from sediments exposed to copper mining residues. Environ. Toxicol. Chem. 2010, 29, 256-264.

53. Singh, D.B.; Tiwary, R.K.; Tewary, B.K. Feldspar for the treatment of As(III) contaminated water. Water Qual. Res. J. Can. 2002, 37, 757-771.

54. Manning, B.A.; Goldberg, S. Adsorption and stability of Arsenic(III) at the clay mineral-water interface. Environ. Sci. Technol. 1997, 31, 2005-2011.

55. Van der Hoek, E.E.; Bonouvrie, P.A.; Comans, R.N.J. Sorption of As and Se on mineral components of fly ash: Relevance for leaching processes. Appl. Geochem. 1994, 9, 403-412.

56. O’Day, P.A. Chemistry and mineralogy of arsenic. Elements 2006, 2, 77-83.

57. Sharma, V.K.; Sohn, M. Aquatic arsenic: Toxicity, speciation, transformations, and remediation. Environ. Int. 2009, 35, 743-759.

58. Newman, D.K.; Ahmann, D.; Morel, F.M.M. A brief review of microbial arsenate respiration. Geomicrobiol. J. 1998, 15, 255-268.

59. Langmuir, D.; Mahoney, J.; Rowson, J. Solubility products of amorphous ferric arsenate and crystalline scorodite $\left(\mathrm{FeAsO}_{4} 2 \mathrm{H}_{2} \mathrm{O}\right)$ and their application to arsenic behavior in buried mine tailings. Geochim. Cosmochim. Acta 2006, 70, 2942-2956.

60. Praharaj, T.; Fortin, D. Seasonal variations of microbial sulfate and iron reduction in alkaline $\mathrm{PbZn}$ mine tailings (Ontario, Canada). Appl. Geochem. 2008, 23, 3728-3740.

61. Mattes, A.; Gould, D.; Taupp, M.; Glasauer, S. A novel autotrophic bacterium isolated from an engineered wetland system links nitrate-coupled iron oxidation to the removal of As, $\mathrm{Zn}$ and S. Water Air Soil Pollut. 2013, 224, doi:10.1007/s11270-013-1490-8.

62. Mattes, A.G. The Trail Biochemical Reactor and the Removal of Arsenic with a Focus on the Specfic Role of Iron. Ph.D. Thesis, University of Guelph, Guelph, Canada, August 2013.

(c) 2013 by the authors; licensee MDPI, Basel, Switzerland. This article is an open access article distributed under the terms and conditions of the Creative Commons Attribution license (http://creativecommons.org/licenses/by/3.0/). 